Prepared in cooperation with the Louisiana Department of Transportation and Development

\title{
Water Resources of Allen Parish
}

\section{Introduction}

In 2005, approximately 29.2 million gallons per day (Mgal/d) of water were withdrawn in Allen Parish, Louisiana (fig. 1), including about $26.8 \mathrm{Mgal} / \mathrm{d}$ from groundwater sources and $2.45 \mathrm{Mgal} / \mathrm{d}$ from surface-water sources ${ }^{1}$ (table 1). Rice irrigation accounted for 74 percent $(21.7 \mathrm{Mgal} / \mathrm{d})$ of the total water withdrawn. Other categories of use included public supply, industrial, rural domestic, livestock, general irrigation,

${ }^{1}$ Tabulation of numbers across text and tables may result in different totals because of rounding; nonrounded numbers are used for calculation of totals. and aquaculture (table 2). Water-use data collected at 5-year intervals from 1960 to 2005 indicate water withdrawals in the parish were greatest in $1960(119 \mathrm{Mgal} / \mathrm{d})$ and 1980 (98.7 Mgal/d) (fig. 2). The substantial decrease in surface-water use between 1960 and 1965 is primarily attributable to riceirrigation withdrawals declining from 61.2 to $6.74 \mathrm{Mgal} / \mathrm{d}$.

This fact sheet summarizes information on the water resources of Allen Parish, Louisiana. Information on groundwater and surface-water availability, quality, development, use, and trends is based on previously published reports listed in the Selected References section.
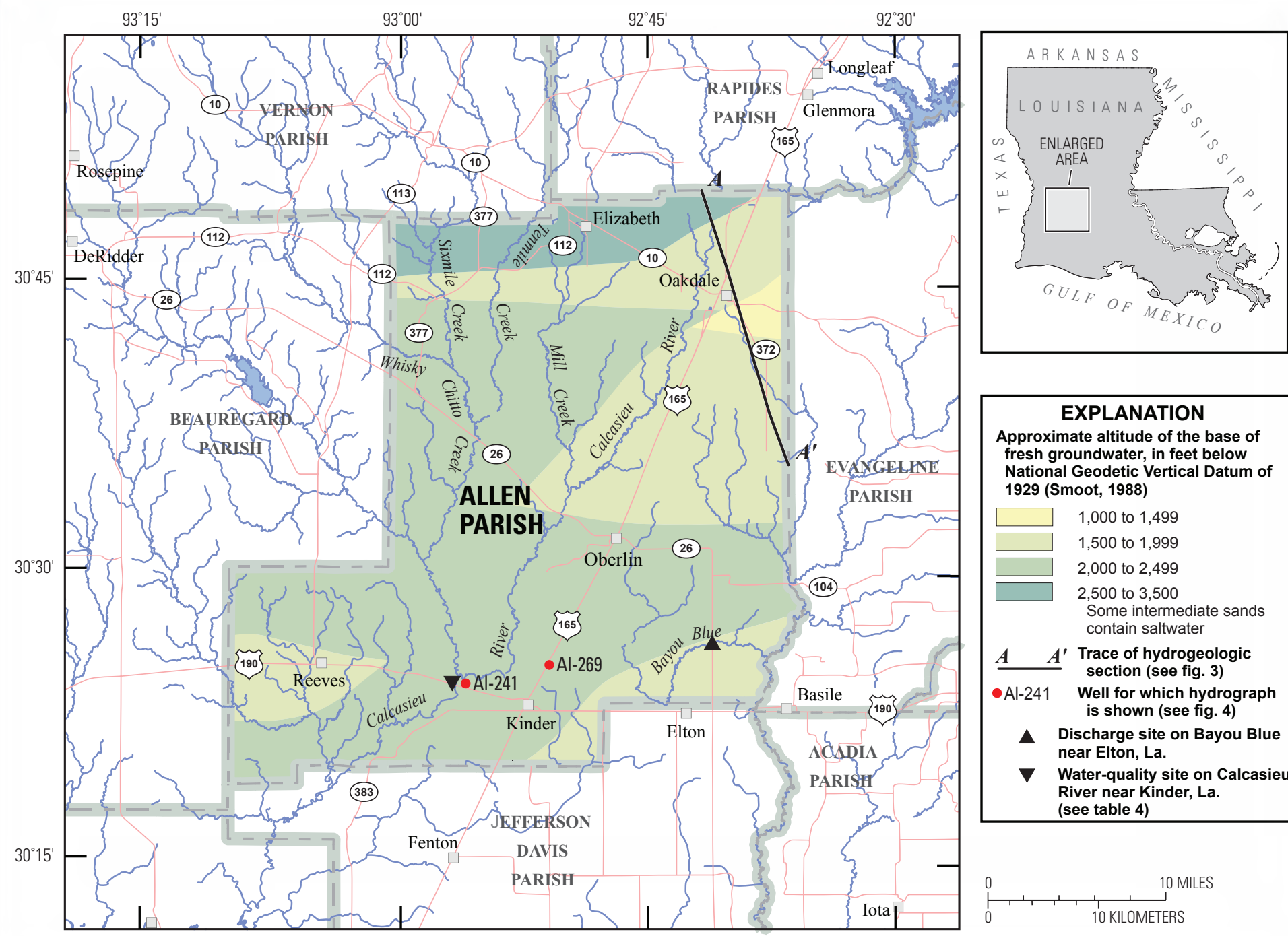

\section{EXPLANATION}

Approximate altitude of the base of fresh groundwater, in feet below National Geodetic Vertical Datum of 1929 (Smoot, 1988)

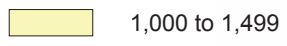

1,500 to 1,999

2,000 to 2,499

2,500 to 3,500

Some intermediate sands contain saltwater

$A \quad A^{\prime}$ Trace of hydrogeologic section (see fig. 3 )

Al-241 Well for which hydrograph is shown (see fig. 4)

A Discharge site on Bayou Blue near Elton, La.

V Water-quality site on Calcasieu River near Kinder, La. (see table 4)

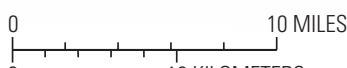

Base map modified from Louisiana Department of Transportation and Development (1986)

Figure 1. Location of study area, Allen Parish, Louisiana. 
Table 1. Water withdrawals, in million gallons per day, by source in Allen Parish, Louisiana, 2005 (modified from Sargent, 2007).

\begin{tabular}{lcc}
\hline $\begin{array}{l}\text { Aquifer, aquifer system, or } \\
\text { surface-water body }\end{array}$ & Groundwater & Surface water \\
\hline Chicot aquifer system & 23.07 & \\
Evangeline aquifer & 3.68 & .33 \\
Bayou Blue & & 2.10 \\
Calcasieu River & & .02 \\
Miscellaneous streams & 26.75 & 2.45 \\
\cline { 2 - 3 } Total & &
\end{tabular}

Table 2. Water withdrawals, in million gallons per day, by category in Allen Parish, Louisiana, 2005 (modified from Sargent, 2007).

\begin{tabular}{lccc}
\hline Category & Groundwater & $\begin{array}{c}\text { Surface } \\
\text { water }\end{array}$ & \multicolumn{1}{c}{ Total } \\
\hline Public supply & 3.71 & 0.00 & 3.71 \\
Industrial & .07 & .00 & .07 \\
Rural domestic & .25 & .00 & .25 \\
Livestock & .06 & .02 & .08 \\
Rice irrigation & 19.51 & 2.23 & 21.74 \\
General irrigation & .20 & .00 & .20 \\
Aquaculture & 2.95 & .21 & 3.15 \\
\cline { 2 - 4 } Total & 26.75 & 2.45 & 29.20 \\
\hline
\end{tabular}

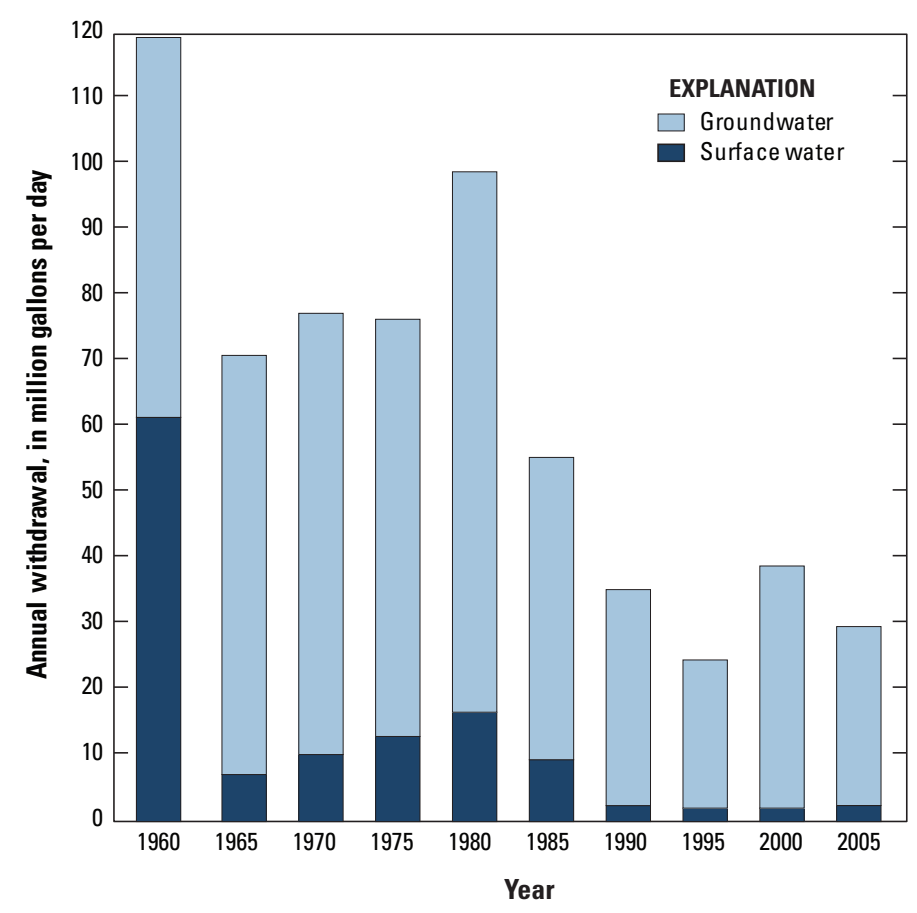

Figure 2. Water withdrawals in Allen Parish, Louisiana, 1960-2005.

\section{Groundwater Resources}

The primary groundwater resources of Allen Parish, from near surface to deepest, include the Chicot aquifer system, Evangeline aquifer, and Jasper aquifer system (fig. 3). The Chicot aquifer system and Evangeline aquifer contain freshwater throughout the parish. The Jasper aquifer system contains freshwater in the northwestern half of the parish and saltwater (water with chloride concentrations greater than 250 milligrams per liter $[\mathrm{mg} / \mathrm{L}])$ in the southeastern half. The base of fresh groundwater generally ranges from about 1,500 to 3,500 feet (ft) below the National Geodetic Vertical Datum of 1929 (NGVD 29) (sea level) in the northwestern half of the parish and from about 1,500 to 2,200 ft below NGVD 29 in the southeastern half of the parish (fig. 1).

Recharge to aquifers in the parish is from rainfall, leakage from overlying aquifers, and seasonally from rivers. Discharge from the aquifers is by natural flow into rivers, leakage into underlying aquifers, and withdrawals from wells.

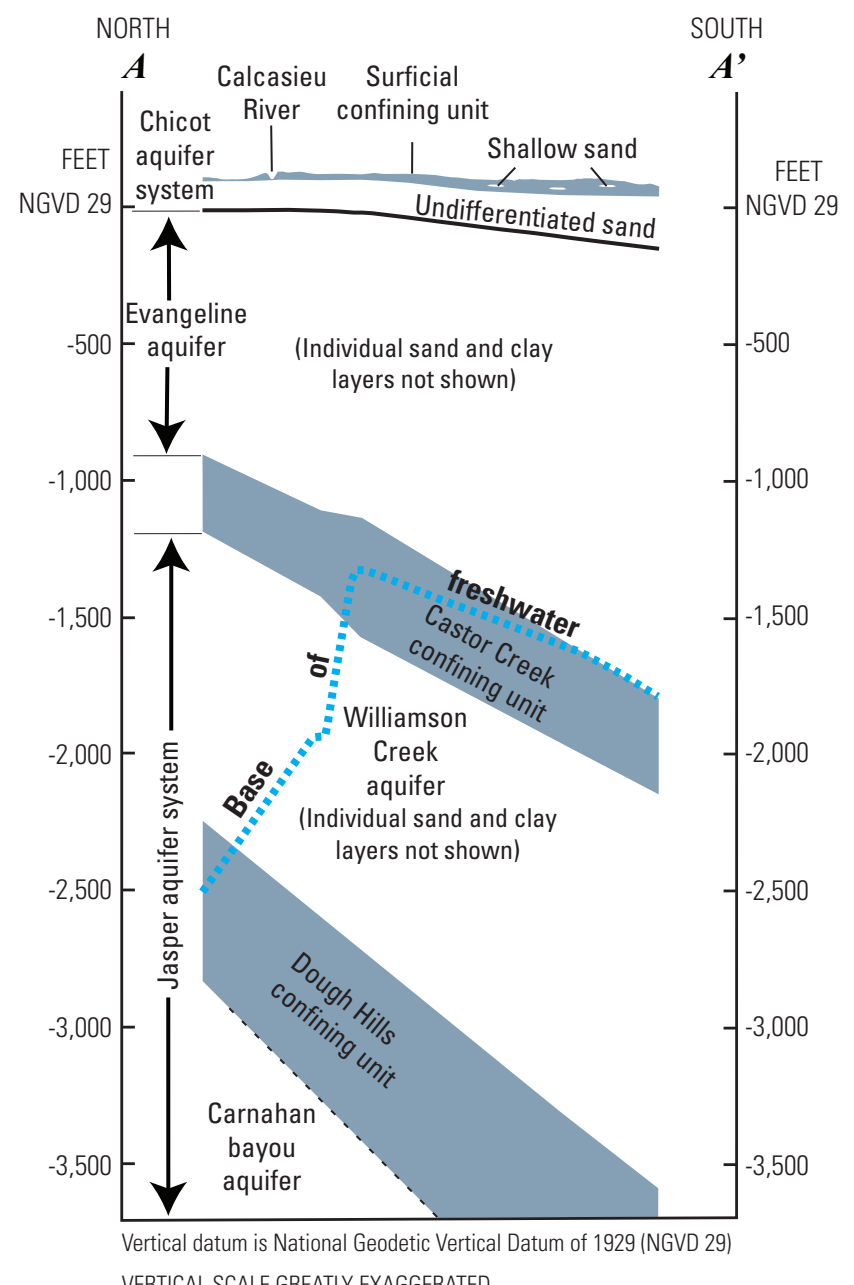
VERTICAL SCALE GREATLY EXAGGERATED
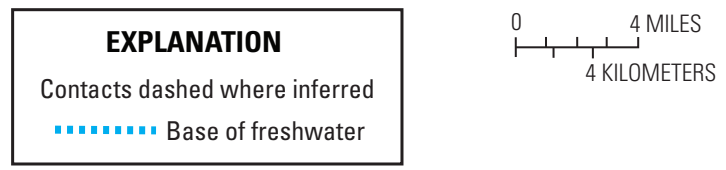

Figure 3. Generalized north-to-south hydrogeologic section through Allen Parish, Louisiana, showing aquifer and confining unit intervals (modified from Whitfield, 1975, pl. 4). Trace of section is shown on figure 1. 
State well-registration records listed 621 active water wells in Allen Parish in 2010, including 355 domestic, 211 irrigation, 42 public-supply, and 13 industrial wells. In 2005, groundwater withdrawals for various uses included public supply, industrial, rural domestic, livestock, rice irrigation, general irrigation, and aquaculture (table 2).

\section{Chicot Aquifer System}

In Allen Parish, the Chicot aquifer system consists of the shallow sand and the deeper undifferentiated sand. The shallow sand is present as scattered sand streaks, lenses, and beds within a surficial clay confining unit (fig. 3). The confining unit generally ranges in thickness from 40 to $80 \mathrm{ft}$ and is less than $40 \mathrm{ft}$ in some areas of the parish. State well-registration records listed 75 active water wells screened in the shallow sand in Allen Parish in 2010, including 71 domestic, 2 irrigation, and 2 public-supply wells. Depths of these wells ranged from 13 to $100 \mathrm{ft}$ below land surface, with a median depth of $32 \mathrm{ft}$. In 2005, water withdrawals from the shallow sand of the Chicot aquifer system in Allen Parish totaled about $0.09 \mathrm{Mgal} / \mathrm{d}$.

The undifferentiated sand is present throughout Allen Parish and is the primary component of the Chicot aquifer system within the parish. It typically underlies the surficial confining unit and is composed of beds of clay, silt, sand, and gravel. Individual beds of sand are usually massive and can attain thickness of several hundred feet. Individual sand beds usually contain fine sand at the top and grade to coarse sand and gravel at the base. The undifferentiated sand dips and thickens towards the south and southeast. The altitude of the base of the undifferentiated sand ranges from about $0 \mathrm{ft}$ NGVD 29 near the northern parish line to about 400-500 ft below NGVD 29 along the southern parish line.
Infiltration of precipitation in southern Vernon and Rapides Parishes, northern Beauregard Parish, and northern Allen Parish is the primary source of recharge to the Chicot aquifer system in Allen Parish. Vertical leakage through clays is a secondary source.

In 2003, water levels in the undifferentiated sand in Allen Parish ranged from about $120 \mathrm{ft}$ above NGVD 29 near the Allen-Vernon Parish line to nearly $40 \mathrm{ft}$ below NGVD 29 in the southeastern corner of the parish. Water movement in the undifferentiated sand in Allen Parish generally is to the south or southeast. Water levels in the undifferentiated sand generally fluctuate $5 \mathrm{ft}$ or more because of seasonal withdrawals, as shown in the hydrograph of well Al-241 (fig. 4), located northwest of Kinder in southern Allen Parish (fig. 1).

State well-registration records listed 443 active water wells screened in the undifferentiated sand in Allen Parish in 2010, including 238 domestic, 190 irrigation, 12 public-supply, and 3 industrial wells. Depths of these wells ranged from 16 to $450 \mathrm{ft}$ below land surface, with a median depth of $130 \mathrm{ft}$. Reported yields from wells screened in the undifferentiated sand in Allen Parish ranged from less than 10 to 7,000 gallons per minute (gal/min).

In 2005, withdrawals from the undifferentiated sand of the Chicot aquifer system in Allen Parish were about $23.0 \mathrm{Mgal} / \mathrm{d}$ and included about $0.10 \mathrm{Mgal} / \mathrm{d}$ for public supply, $0.21 \mathrm{Mgal} / \mathrm{d}$ for rural domestic use, $0.02 \mathrm{Mgal} / \mathrm{d}$ for livestock, $19.5 \mathrm{Mgal} / \mathrm{d}$ for rice irrigation, $0.20 \mathrm{Mgal} / \mathrm{d}$ for general irrigation, and $2.95 \mathrm{Mgal} / \mathrm{d}$ for aquaculture.

A statistical summary of selected water-quality characteristics for 81 wells screened in the undifferentiated sand in Allen Parish is listed in table 3. Generally, water from the undifferentiated sand is soft ( $60 \mathrm{mg} / \mathrm{L}$ or less as calcium carbonate) and does not exceed the U.S. Environmental Protection Agency's (EPA)

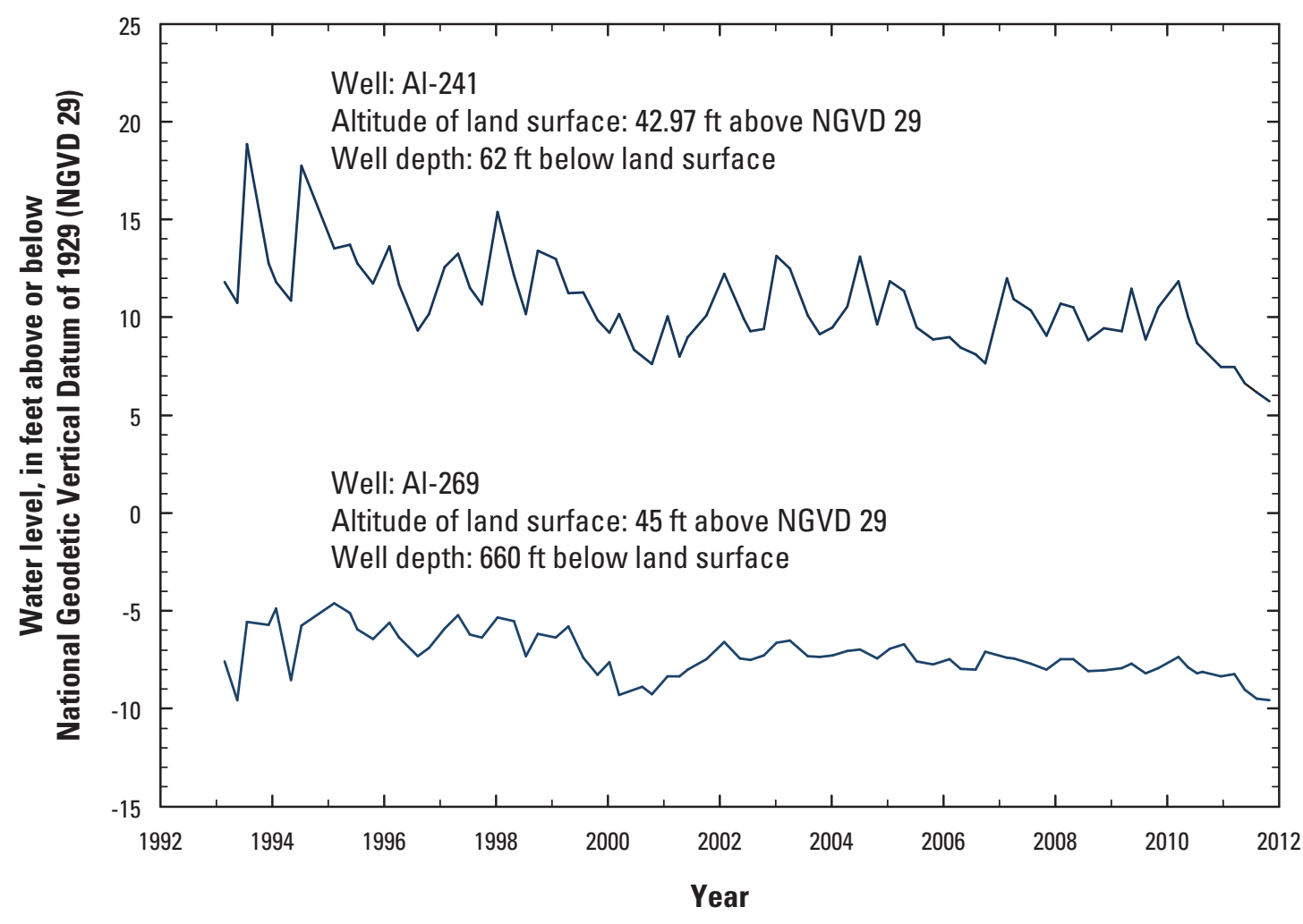

Figure 4. Water levels in well Al-241 screened in the Chicot aquifer system (undifferentiated sand) and well Al-269 screened in the Evangeline aquifer in Allen Parish, Louisiana (see fig. 1 for well locations; U.S. Geological Survey, 2012a). Land surface is measured in feet above the National Geodetic Vertical Datum of 1929 (NGVD 29). 
Table 3. Summary of selected water-quality characteristics of freshwater in the Chicot aquifer system (undifferentiated sand) and Evangeline aquifer in Allen Parish, Louisiana (U.S. Geological Survey, 2012b).

[Values are in milligrams per liter, except as noted. ${ }^{\circ} \mathrm{C}$, degrees Celsius; $\mathrm{PCU}$, platinum cobalt units; $\mu \mathrm{S} / \mathrm{cm}$, microsiemens per centimeter; SU, standard units; $\mathrm{CaCO}_{3}$, calcium carbonate; $\mu \mathrm{g} / \mathrm{L}$, micrograms per liter; <, less than; NA, not applicable; SMCL, Secondary Maximum Contaminant Level established by the U.S. Environmental Protection Agency (2011)]

\begin{tabular}{|c|c|c|c|c|c|c|c|c|c|}
\hline & $\begin{array}{c}\text { Temper- } \\
\text { ature }\left({ }^{\circ} \mathrm{C}\right)\end{array}$ & $\begin{array}{l}\text { Color, } \\
\text { (PCU) }\end{array}$ & $\begin{array}{c}\text { Specific } \\
\text { conductance, } \\
\text { field } \\
(\mu \mathrm{S} / \mathrm{cm} \text { at } \\
\left.25^{\circ} \mathrm{C}\right)\end{array}$ & $\begin{array}{l}\text { pH, } \\
\text { field } \\
\text { (SU) }\end{array}$ & $\begin{array}{l}\text { Hardness } \\
\text { (as } \mathrm{CaCO}_{3} \text { ) }\end{array}$ & $\begin{array}{c}\text { Chloride, } \\
\text { filtered } \\
\text { (as CI) }\end{array}$ & $\begin{array}{c}\text { Iron, } \\
\text { filtered } \\
\text { ( } \mu \mathrm{g} / \mathrm{L} \text { as } \\
\mathrm{Fe})\end{array}$ & $\begin{array}{c}\text { Manganese, } \\
\text { filtered } \\
\text { ( } \mu \mathrm{g} / \mathrm{L} \text { as } \mathrm{Mn})\end{array}$ & $\begin{array}{l}\text { Dissolved } \\
\text { solids, } \\
\text { filtered }\end{array}$ \\
\hline \multicolumn{10}{|c|}{ Chicot aquifer system (undifferentiated sand), 1940-2008 (81 wells) } \\
\hline Median & 20.7 & 5 & 151 & 6.2 & 30 & 18 & 200 & 55 & 120 \\
\hline 10th percentile & 20.0 & 0 & 62 & 5.3 & 6 & 5.5 & $<10$ & $<1$ & 46 \\
\hline 90th percentile & 21.5 & 28 & 271 & 7.9 & 73 & 32 & 6,700 & 540 & 206 \\
\hline Number of samples & 51 & 13 & 55 & 44 & 59 & 80 & 31 & 28 & 40 \\
\hline $\begin{array}{l}\text { Percentage of samples } \\
\text { that do not exceed } \\
\text { SMCLs }\end{array}$ & NA & 77 & NA & 41 & NA & 100 & 55 & 50 & 100 \\
\hline \multicolumn{10}{|c|}{ Evangeline aquifer, 1946-95 (44 wells) } \\
\hline Median & 23.5 & 10 & 321 & 8.2 & 5 & 8.0 & 230 & 20 & 230 \\
\hline 10th percentile & 21.5 & 5 & 255 & 7.2 & 2 & 4.8 & 50 & 0 & 193 \\
\hline 90th percentile & 25.0 & 140 & 764 & 8.6 & 26 & 25 & 870 & 76 & 494 \\
\hline Number of samples & 33 & 41 & 42 & 43 & 43 & 44 & 41 & 33 & 40 \\
\hline $\begin{array}{l}\text { Percentage of samples } \\
\text { that do not exceed } \\
\text { SMCLs }\end{array}$ & NA & 59 & NA & 84 & NA & 100 & 61 & 85 & 90 \\
\hline \multicolumn{10}{|c|}{ SMCLs } \\
\hline & NA & 15 & NA & $6.5-8.5$ & NA & 250 & 300 & 50 & 500 \\
\hline
\end{tabular}

Secondary Maximum Contaminant Levels (SMCLs) ${ }^{2}$ for drinking water for color or for concentrations of chloride, iron, and dissolved solids. Locally, iron concentrations can exceed the SMCL of 300 micrograms per liter $(\mu \mathrm{g} / \mathrm{L})$. Manganese concentrations are generally greater than the SMCL of $50 \mu \mathrm{g} / \mathrm{L}$. The median $\mathrm{pH}$ value of 6.2 is below the SMCL range of $6.5-8.5$.

\section{Evangeline Aquifer}

The Evangeline aquifer is present throughout Allen Parish and underlies the Chicot aquifer system (fig. 3). It consists primarily of fine to medium sand interbedded with silt, soft to moderately hard green-gray laminated clay, and local beds of coarse sand. Locally, sands within the aquifer are separated and confined by extensive clays. The altitude of the top of the aquifer is equivalent to the base of the Chicot aquifer system and is about $0 \mathrm{ft}$ NGVD 29 near the northern parish line and about 400-500 ft below NGVD 29 near the southern parish

\footnotetext{
${ }^{2}$ The SMCLs are nonenforceable Federal guidelines regarding cosmetic effects (such as tooth or skin discoloration) or aesthetic effects (such as taste, odor, or color) of drinking water. At high concentrations or values, health implications as well aesthetic degradation might exist. SMCLs were established as guidelines for the states by the U.S. Environmental Protection Agency (1992).
}

line. The approximate thickness of the Evangeline aquifer in Allen Parish ranges from $900 \mathrm{ft}$ near the northern parish line to $2,000 \mathrm{ft}$ near the southern parish line. The aggregate thickness of freshwater sands in the aquifer ranges from about $200 \mathrm{ft}$ near the southern parish line to about $1,000 \mathrm{ft}$ in the western-central area of the parish. Near the town of Elizabeth, aggregate freshwater sand thickness is about $400 \mathrm{ft}$.

In 2003, water levels in the aquifer generally ranged from about $140 \mathrm{ft}$ above NGVD 29 in the northwestern corner of the parish to about $40 \mathrm{ft}$ below NGVD 29 in its southeastern corner. Water levels at well Al-269, located northeast of the town of Kinder in southern Allen Parish (fig. 1), have generally ranged between 5 and $10 \mathrm{ft}$ below NGVD 29 since 1993 (fig. 4). Water movement in the Evangeline aquifer in Allen Parish is generally towards the south-southeast.

State well-registration records listed 34 active water wells screened in the Evangeline aquifer in Allen Parish in 2010, including 25 for public supply, 8 for industrial use, and 1 for domestic use. Depths of these wells ranged from 390 to $1,720 \mathrm{ft}$ below land surface with a median depth of $749 \mathrm{ft}$. Yields from wells screened in the Evangeline aquifer in Allen Parish reportedly range from about 9 to $1,000 \mathrm{gal} / \mathrm{min}$. In 2005, withdrawals from the Evangeline aquifer in Allen Parish were about $3.68 \mathrm{Mgal} / \mathrm{d}$ (table 1) and included about 3.61 Mgal/d for public supply and $0.07 \mathrm{Mgal} / \mathrm{d}$ for industrial use. 
A statistical summary of selected water-quality characteristics for 44 wells screened in the Evangeline aquifer in Allen Parish is listed in table 3. Generally, water from the Evangeline aquifer is soft and does not exceed the SMCLs for drinking water for color and $\mathrm{pH}$ or for concentrations of chloride, iron, manganese, and dissolved solids. Locally, color and concentrations of iron and manganese may exceed their SMCLs.

\section{Jasper Aquifer System}

The Jasper aquifer system underlies all of Allen Parish and consists of the Williamson Creek aquifer, Dough Hills confining unit, and Carnahan Bayou aquifer (fig. 3). The clayey Castor Creek confining unit separates the Jasper aquifer system from the overlying Evangeline aquifer. The aquifer system contains freshwater in the northern and western parts of the parish. Freshwater is present in all the sands of the aquifer system only in the extreme northwest corner of the parish. Toward the southeast, the base of freshwater becomes progressively shallower (fig. 3), and the number of freshwaterbearing sands and the aggregate thickness of freshwater sands decrease proportionately. Light-gray sands with occasional traces of granule-size gravel make up approximately 50 percent of the aquifers within the system. The predominantly sandy Williamson Creek and Carnahan Bayou aquifers are composed of generally well-sorted, very fine to medium sands interbedded with greenish-gray clays.

Thickness of the Jasper aquifer system in Allen Parish generally ranges from about 2,500 ft near the town of Elizabeth to over 3,500 ft near the town of Oberlin (fig. 1). The altitude of the top of the aquifer is about 1,300 ft below NGVD 29 near the northern parish line and about 3,000 ft below NGVD 29 near the southern parish line.
State well-registration records did not list any active water wells screened in the Jasper aquifer system in Allen Parish in 2010. Data from test holes drilled into freshwater areas of the Williamson Creek aquifer in Allen Parish indicate the water is soft, with a $\mathrm{pH}$ above 8.0. Iron concentrations generally exceed the SMCL of $300 \mu \mathrm{g} / \mathrm{L}$.

\section{Surface-Water Resources}

In 2005, about $2.45 \mathrm{Mgal} / \mathrm{d}$ of surface water were withdrawn in Allen Parish, including about $2.23 \mathrm{Mgal} / \mathrm{d}$ for rice irrigation, $0.21 \mathrm{Mgal} / \mathrm{d}$ for aquaculture, and $0.02 \mathrm{Mgal} / \mathrm{d}$ for livestock (table 2). About $2.10 \mathrm{Mgal} / \mathrm{d}$ were withdrawn from the Calcasieu River, and $0.33 \mathrm{Mgal} / \mathrm{d}$ were withdrawn from Bayou Blue (table 1). Other notable streams and potential sources of freshwater in the parish include Whisky Chitto, Sixmile, Tenmile, and Mill Creeks (fig. 1).

The mean discharge for the Calcasieu River near Kinder (station number 08015500; U.S. Geological Survey, 2008) from 1923 to 2008 was 2,620 cubic feet per second (1,690 Mgal/d). The drainage area for this site is about 1,700 square miles $\left(\mathrm{mi}^{2}\right)$. Water samples analyzed during the period 1966-98 indicate water in the Calcasieu River near Kinder (fig. 1) is generally soft (table 4) and does not exceed the SMCLs for drinking water concentrations of chloride and sulfate. The $\mathrm{pH}$ is generally below the SMCL of 6.5 to 8.5 standard units, and iron concentrations can exceed the SMCL of $300 \mu \mathrm{g} / \mathrm{L}$. Dissolved oxygen is generally greater than $5 \mathrm{mg} / \mathrm{L}$, which is considered the minimum value for a diversified population of fresh, warmwater biota, including sport fish (Louisiana Department of Environmental Quality, 2008).

The drainage area for Bayou Blue at Louisiana Highway 26 near Elton (station number 303209092401800 ; U.S. Geological Survey, 2012c) (fig. 1) is about $94 \mathrm{mi}^{2}$. No discharge data and few water-quality data are available for the bayou.

Table 4. Summary of selected water-quality characteristics for the Calcasieu River in Allen Parish, Louisiana, 1966-98.

[Values are in milligrams per liter, except as noted. ${ }^{\circ} \mathrm{C}$, degrees Celsius; $\mu \mathrm{S} / \mathrm{cm}$, microsiemens per centimeter; SU, standard units; $\mu \mathrm{g} / \mathrm{L}$, micrograms per liter; $\mathrm{CaCO}_{3}$, calcium carbonate; <, less than; NA, not applicable; SMCL, Secondary Maximum Contaminant Level established by the U.S. Environmental Protection Agency (2011)]

\begin{tabular}{|c|c|c|c|c|c|c|c|c|c|c|}
\hline & $\begin{array}{c}\text { Specific } \\
\text { conductance, } \\
\text { field }(\mu \mathrm{S} / \mathrm{cm} \\
\left.\text { at } 25^{\circ} \mathrm{C}\right)\end{array}$ & $\begin{array}{l}\text { Oxygen, } \\
\text { dis- } \\
\text { solved }\end{array}$ & $\begin{array}{l}\text { pH, field } \\
\text { (SU) }\end{array}$ & $\begin{array}{l}\text { Hard- } \\
\text { ness } \\
\text { (as } \\
\mathrm{CaCO}_{3} \text { ) }\end{array}$ & $\begin{array}{l}\text { Calcium, } \\
\text { filtered } \\
\text { (as Ca) }\end{array}$ & $\begin{array}{l}\text { Mag- } \\
\text { nesium, } \\
\text { filtered } \\
\text { (as } \mathbf{M g )}\end{array}$ & $\begin{array}{l}\text { Sodium, } \\
\text { filtered } \\
\text { (as Na) }\end{array}$ & $\begin{array}{l}\text { Chlo- } \\
\text { ride, } \\
\text { filtered } \\
\text { (as CI) }\end{array}$ & $\begin{array}{l}\text { Sulfate, } \\
\text { filtered } \\
\text { (as } \mathrm{SO}_{4} \text { ) }\end{array}$ & $\begin{array}{c}\text { Iron, } \\
\text { filtered } \\
(\mu \mathrm{g} / \mathrm{L} \\
\text { as Fe) }\end{array}$ \\
\hline \multicolumn{11}{|c|}{ Calcasieu River near Kinder, Louisiana' } \\
\hline Median & 56 & 8.4 & 6.4 & 11 & 2.8 & 0.9 & 5.3 & 5.4 & 4.0 & 260 \\
\hline 10th percentile & 32 & 6.9 & 5.7 & 7 & 1.9 & 0.5 & 2.6 & 3.2 & 2.0 & 130 \\
\hline Number of samples & 110 & 98 & 110 & 110 & 110 & 110 & 105 & 109 & 105 & 64 \\
\hline $\begin{array}{l}\text { Percentage of } \\
\text { samples that } \\
\text { do not exceed } \\
\text { SMCLs }\end{array}$ & NA & NA & 46 & NA & NA & NA & NA & 100 & 100 & 64 \\
\hline
\end{tabular}

\begin{tabular}{|c|c|c|c|c|c|c|c|c|c|}
\hline \multicolumn{10}{|c|}{ SMCLs } \\
\hline NA & NA & $6.5-8.5$ & NA & NA & NA & NA & 250 & 250 & 300 \\
\hline
\end{tabular}




\section{Selected References}

Fendick, R.B., Jr., 2005, Louisiana ground-water map no. 21Generalized potentiometric surface of the Evangeline aquifer in south-central Louisiana, 2004: U.S. Geological Survey Scientific Investigations Map 2880, 1 sheet, accessed January 5, 2010, at http://pubs.usgs.gov/sim/2880/plate-1.pdf.

Harder, A.H., Kilburn, Chabot, Whitman, H.M., and Rogers, S.M., 1967, Effects of ground-water withdrawals on water levels and saltwater encroachment in southwestern Louisiana: Department of Conservation, Louisiana Geological Survey, and Louisiana Department of Public Works Water Resources Bulletin no. 10, 56 p.

Louisiana Department of Environmental Quality, 2008, Environmental Regulatory Code, Title 33, Part IX, Subpart 1: Baton Rouge, Louisiana Department of Environmental Quality, accessed June 9, 2009, at http:www.deq.louisiana.gov/portal/ tabid/1674/Default.aspx.

Louisiana Department of Transportation and Development, 1986 , Official map of Louisiana-1986 edition: Baton Rouge, Louisiana Department of Transportation and Development, 1 sheet.

Lovelace, J.K., Fontenot, J.W., and Frederick, C.P., 2004, Withdrawals, water levels, and specific conductance in the Chicot aquifer system in southwestern Louisiana, 2000-03: U.S. Geological Survey Scientific Investigations Report 2004$5212,56 \mathrm{p}$.

Nyman, D.J., 1989, Quality of water in freshwater aquifers in southwestern Louisiana: Louisiana Department of Transportation and Development Water Resources Technical Report no. 42, 22 p., 28 pls.

Sargent, B.P., 2004, Thickness of the Chicot aquifer system surficial confining unit and location of shallow sands, southwestern Louisiana: Louisiana Department of Transportation and Development Water Resources Technical Report no. 73, 29 p.

Sargent, B.P., 2007, Water use in Louisiana, 2005: Louisiana Department of Transportation and Development Water Resources Special Report no. 16, 133 p.

Smoot, C.W., 1988, Louisiana hydrologic atlas map no. 3- Altitude of the base of freshwater in Louisiana: U.S. Geological Survey Water-Resources Investigations Report 86-4314, 1 sheet, accessed November 2, 2011, at http://pubs.usgs.gov/wri/1986/4314/ plate-1.pdf.

U.S. Environmental Protection Agency, 1992, Secondary Drinking Water Regulations-Guidance for nuisance chemicals: U.S. Environmental Protection Agency publication EPA 810/K-92-001, 4 p., accessed July 29, 2009, at http://www.epa.gov/safewater/ consumer/2ndstandards.html.

U.S. Environmental Protection Agency, 2011, 2011 Edition of the drinking water standards and health advisories: U.S. Environmental Protection Agency, Office of Water, EPA 820-R11-002, 12 p., accessed September 2, 2011, at http://water.epa.gov/ action/advisories/drinking/upload/dwstandards2011.pdf.
U.S. Geological Survey, 2008, Annual water data reports-Waterdata report 2008 [data for USGS 08015500 Calcasieu River near Kinder, LA]: U.S. Geological Survey Water Resources of the United States, accessed November 6, 2009, at http://wdr.water.usgs. gov/wy2008/pdfs/08015500.2008.pdf.

U.S. Geological Survey, 2012a, Ground-water levels for Louisiana: National Water Information System Web Interface, accessed November 18, 2011, at http://nwis.waterdata.usgs.gov/la/nwis/ gwlevel/.

U.S. Geological Survey, 2012b, Water quality samples for Louisiana: National Water Information System Web Interface, accessed February 18, 2009, at http://nwis.waterdata.usgs.gov/la/nwis/ qwdata/.

U.S. Geological Survey, 2012c, U.S. Geological Survey water data for Louisiana [for site 303209092401800 Bayou Blue at LA-Hwy 26 near Elton, LA.]: National Water Information System Web Interface, accessed January 5, 2010, at http://nwis.waterdata.usgs. gov/la/nwis/nwisman/?site_no=303209092401800.

Whitfield, M.S., Jr., 1975, Geohydrology of the Evangeline and Jasper aquifers of southwestern Louisiana: Department of Conservation, Louisiana Geological Survey, and Louisiana Department of Public Works Water Resources Bulletin no. 20, 72 p.

\section{By Lawrence B. Prakken , Jason M. Griffith, and Robert B. Fendick, Jr}

\section{For additional information, contact:}

Director, USGS Louisiana Water Science Center 3535 S. Sherwood Forest Blvd., Suite 120

Baton Rouge, LA 70816

E-mail: dc_la@usgs.gov

Fax: (225) 298-5490

Telephone: (225) 298-5481

Home Page: http://la.water.usgs.gov

This fact sheet was published by the U.S. Geological Survey, in cooperation with the Louisiana Department of Transportation and Development (DOTD). Thanks are given to Zahir "Bo" Bolourchi, Director, Water Resources Programs, Louisiana Department of Transportation and Development, who contributed to the content and design of the fact sheet. 